\title{
MENGURAI PEMIKIRAN PLURALISMe agama NASR DAN HICK
}

\section{Adnan Aslan, Menyingkap Kebenaran: Pluralisme Agama dalam Filsafat Islam} dan Kristen Seyyed Hossein Nasr \& John Hick, penerjemah Munir, Cetakan 1, April 2004, Bandung: Alifya, ISBN: 979-98490-0-4, harga Rp. 45.000,-.

W acana pluralisme agama senantiasa menarik untuk dikaji, baik pada tataran konseptual.maupun secara riil praksis. Pro dan kontra terhadap wacana ini pun sangat kuat. Bagi pendukungnya, pluralisme agama sudah dianggap sebagai hukum Tuhan (sunnatullah) yang tidak mungkin berubah. Banyaknya konflik antarumat beragama, dikarenakan tidak adanya kesadaran terhadap pluralisme agama ini. Sementara itu, bagi penentangnya, pluralisme agama adalah 'agama baru', yang jika ide ini dikembangkan di negara yang mayoritas penduduknya adalah Islam, maka akan berdampak besar pada proses de-islamisasi.

Bagi pendukungnya sendiri, meski setuju dengan gagasan pluralisme agama, konseptualisasi terhadap ide ini sangatlah bervariasi. Inilah yang nampaknya hendak dibidik oleh Adnan Aslan dalam karyanya yang judul aslinya Religious Pluralisme in Christian and Islamic Philosophy: The Thought of John Hick and Seyyed Hossein Nasr, diterbitkan oleh Curzon Press, London, tahun 1998, dan kemudian diterjemahkan ke dalam bahasa Indonesia menjadi Menyingkap Kebenaran: Pluralisme Agama dalam Filsafat Islam dan Kristen Seyyed Hossein Nasr \& John Hick.

Dalam karyanya ini, yang merupakan disertasi pada Lancaster University, Inggris pada 1995, di bawah bimbingan Prof. Oliver Leaman dan Prof. John Clayton, Adnan Aslan mencoba membandingkan gagasan dua filosof kontemporer, sekaligus tokoh terkemuka pluralisme agama, yaitu John Hick dan Seyyed Hossein Nasr.

Sekilas, Aslan, yang juga peneliti pada Center for Islamic Studies, Istanbul, Turkey, terlihat berupaya mengkaji pandangan-pandangan dua tokoh di atas mengenai masalah agama, agama-agama, konsep realitas tertinggi dan gagasan tentang pengetahuan yang sakral. Namun, sebenarnya pada tingkat yang lebih luas bisa dikatakan, Aslan telah membandingkan dua pandangan dunia, mengkaji pandangan dunia yang dibentuk oleh budaya Barat, yang tujuannya bersifat religius tapi esensinya sekular, berhadapan dengan dua pandangan dunia yang dibentukmelalui asimilasi hikmah tradisional, yang bertentangan dengan norma budaya sekular, dan karenanya, tujuan dan esensinya bersifat religius.

$$
* * * * *
$$

Dalam pembahasan klaim-klaim kebenaran agama, studi-studi agama kontemporer umumnya dibedakan ke dalam tiga paradigma: pluralisme, eksklusivisme dan inklusivisme. Paradigma pluralis dicirikan sebagai suatu paradigma yang mengklaim bahwa agama-agama yang berbeda dapat memberikan jalan keselamatan menuju Tuhan 
YangMaha Esa. Eksklusivisme mengklaim kesahihan satu agama sebagai jalan keselamatan menuju Tuhan, sedang inklusivisme melihat agama lain hanya sebagai pemenuhan jalanjalan lain.

Dari ketiga paradigma di atas, yang menjadi perhatian utama pada kajian ini, yaitu pluralisme. Sejauh yang dipaparkan penulis, memang ada banyak ragam dari paradigma pluralisme. Dua yang dibidik, yaitu Nasr dan Hick. Bagi Nasr, kebenaran adalah kebenaran-kebenaran agama wahyu, yang harus kita dilakukan adalah tunduk di hadapan kebenaran semacam itu dan menerimanya tanpa mengubahnya. Tugas kita, tegas Nasr, bukan menemukan kebenaran, tetapi sikap terbuka terhadap kebenaran dan memantulkan sebagaimana adanya. Adapun bagi Hick, pluralisme adalah kebenaran dan karenanya agama-agama harus memodifikasi kebenaran mereka menuju kebenaran plural dengan melakukan revisi substansial atas ajaran-ajaran teologis mereka.

Gagasan-gagasan yang dipegang itu, tak ragu lagi, mempengaruhi metode dan sumbangan intelektual yang mereka berikan pada wilayah studi agama. Hick percaya kepada akal, ilmu pengetahuan dan kemampuan manusia untuk menciptakan kebaikan. Pandangan-pandangannya jelas dan terperinci, dan bergerak dalam kerangka tradisi filsafat Barat. Nasr di sisi lain, meyakini akal itu terbatas, dan menganggap ilmu pengetahuan sekular dan tidak relevan dalam pencarian kita terhadap Yang Riil. Nasr percaya bahwa inteleksi-lah (visi mistis) yang memainkan peran penting dalam persepsi kita tentang Realitas, bukan akal. Karena itu, Nasr tidak bergerak dalam kerangka tradisi filsafat Barat (hal. xvii).

Bentuk jelas dari perbedaan cara pandang ini, bisa dilihat dari gagasan keduanya tentang masalah keterkaitan agama dengan sejarah. Hick melihat sejarah seperti kekuatan yang tidak hanya mengatur manusia, tetapi juga mengantarkan masyarakat pada tujuan tertentu(hal.59). Pandangan ini bisa dikatakan mewakili kecenderungan pemikiran modem yang kemudian melihat agama melalui variasi atau arus kehidupan agama yang selalu berubah, karenanya perhatian utama diberikan pada kegunaan atau fungsi praktis agama (hal. 60).

Adapun menurut Nasr, realitas agama tidak dapat diidentifikasikan hanya berdasarkan penyingkapan historisnya. Setiap agama memiliki benihnya sendiri, yaitu prinsip-prinsip atau kemungkinan-kemungkinannya di wilayah langitnya (archetypes) dalam intelek Tuhan. Yang diturunkan ke alam duniawi ini, sejauh agama diperhatikan, hanyalah manifestasi-manifestasi yang telah ditentukan. Lebih lanjut, Nasr tidak menolak adanya perubahan dalam agama. Tetapi perubahan-perubahan ini dilihat melalui perspektif yang memandang agama sebagai materialisasi gagasan yang telah ada dalam wilayah Tuhan (hal. 61).

Berkenaan dengan problem, bisakah Tuhan diketahui. Ada uraian menarik dari kedua tokoh ini. Bagi Hick pertanyaan seperti ini harus diperjelas. Apakah pertanyaan tersebut pengetahuan tentang (1) tuhan agama-agama; atau (2) pengetahuan tentang 
Yang Riil an sich? Jika pertanyaan itu masuk kategori yang pertama, Hick akan menjawab bahwa pengetahuan tentang Yang Riil an sich pada tingkat fenomenologis selalu mungkin, bukan sebagai pengetahuan Yang Riil itu sendiri, tetapi manifestasinya. Bagi Hick kita dengan mudah mengakses pengetahuan tentang Allah melalui tradisi Islam, Adonai melalui agama Yahudi, Bapak di Surga melalui agama Kristen, Wisnu atau Shiwa melalui agama Hindu dan sebagainya. Namun jika kita bertanya apakah, mungkin memiliki pengetahuan tentang Yang Riil an sich sebagai landasan noumenal bagi tuhan-tuhan fenomenal ini, jawaban Hick pasti tidak (hal. 132).

Pandangan ini berbeda dengan Nasr yang memandang Tuhan dapat diketahui secara metafisis. Bagi Nasr, Tuhan sebagai Realitas dapat diketahui bukan hanya karena manusia dipersenjatai dengan intelek, tetapi juga karena kosmos, agama dan manusia yang ada memiliki suatu substansi sakral yang memanifestasikan Realitas Tertinggi bagi orang-orang yang menyiapkan diri menerima pengetahuan semacam ini (hal. 133).

Terkait dengan masalah globalisasi yang membawa perubahan dalam suatu agama. Hick dengan tegas menyatakan bahwa perkembangan historis dan global dapat menimbulkan perubahan dalam bangunan teologis suatu agama tertentu karena kehidupan keagamaan manusia merupakan wilayah hubungan yang terus menerus dengan Realitas Ilahi. Namun Nasr, mengatakan bahwa globalisasi atau perkembangan historis tidak dapat menimbulkan perubahan dalam tatanan teologis agama tertentu, karena tatanan itu dibangun oleh wahyu. Ia akan menegaskan bahwa kemajuan teknologi komunikasi dan interaksi kultural hanya dapat memberikan suatu konteks bagi penafsiran baru atas doktrin suatu agama tertentu (hal. 148).

Secara khusus tentang gagasan pluralisme agama, Hick sangat meyakini bahwa kita dapat menurunkan bahkan menghapuskan intoleransi dan konflik keagamaan dengan meyakinkan orang beragama bahwa tuhan-tuhan yang mereka sembah adalah manifestasi dari Yang Esa, yakni satu-satunya Yang Riil. Dengan ungkapan lain, sosok tuhan seperti Allah dalam Islam, Adonai dalam Yahudi, Bapak di Surga dalam Kristen, Shiwa dan 'Wisnu dalam Hindu, adalah cara Yang Riil disembah dan diakui. Inilah yang disebut Hick personae dan impersonae Yang Riil.

Terhadap pemikiran ini, penulis memberikan catatan kritisnya. Menurut penulis, pembedaan yang dibuat agama tidak menolak sifat Tuhan, sementara pembedaan yang dilakukan Hick menolaknya. Berangkat dari tradisi Islam, penulis menyatakan. Pertama, pembedaan yang dilakukan Hick tidak diakui oleh aliran utama teologi Islam, juga tidak umum digunakan oleh para sarjana muslim. Muslim percaya bahwa Tuhan mempunyai dzat dan sifat sekaligus, masing-masing sifat menggarisbawahi salah satu aspek Tuhan. Dengan kata lain, tuhan sebagai al Haqq adalah Tuhan yang juga mewahyukan al Qur'an, tuhan Esa yang berhak disembah (hal. 197).

Melihat kajian pada buku ini, nampak bahwa penulis lebih mengkonsentrasikan bahasan pada pemikiran Hick, yang kemudian dikritisi dengan melihat pemikiran Nasr. 
Oleh karenanya, nampak ada sedikit bias. Namun, hal ini kiranya cukup disadari oleh penulis, dengan menyatakan bahwa kajian dia terhadap dua tokoh ini merupakan kajian yang berada dalam wilayah filsafat agama, yang bersifat normatif dan historis, dan tidak berpretensi sebagai kajian yang bebas nilai. Kajian ini dilakukan untuk mengadakan penilaian dan memperoleh justifikasi (hal xii).

Secara umum, buku ini cukup menarik untuk dikaji oleh para akademisi dan masyarakat umum yang ingin mendalami tentang gagasan dan konsep pluralisme agama. Apa yang dikemukakan penulis, nampaknya mengamini ide besar sosiologi pengetahuan yang dikumandangkan oleh Karl Mannheim, bahwa suatu pemikiran tidak bisa lepas dari realitas. Pengetahuan tidak bebas nilai, ia terikat dengan situasi dan kondisi dari si perumus pengetahuan. Hick dan Nasr, dan bahkan Aslan sendiri selaku penulis nampaknya telah terkena hukum ini.

M. Zainal Abidin

Peneliti pada Pusat Studi Islam-UII Yogyakarta 